\title{
Lidia Godzwon, Ph.D.
}

Andrzej Frycz Modrzewski Krakow University

Faculty of Psychology and Humanities

\section{Elżbieta Krawczyk-Pasławska}

Rydgier Hospital Departament of Toxicology

\section{THE DISABLED IN THE REHAB TREATMENT SELECTED THESIS ELEMENTS}

\section{Introduction}

"I was always at home... They came, they were my friends. They brought beer, sometimes vodka but vodka was rather rare, as there were still children at home. I could always count on their company. That was how I met Krzysiek. Now I know that it was a mistake but thanks to him I have a wonderful son... I just hope that I will get him back... that both of my children will come back home. I wasn't that drunk after all... I didn't feel that at all. Everyone was gone and I was left alone...they came with more beer. I'm all alone now, waiting for my children and I'm horribly afraid. I'm not able to leave the house, I'm too ashamed as others feel sorry for me and I don't want their compassion. I don't belong here, as a part of a group, they don't know what it means to be a cripple. They look at me as if they said that in my situation drinking was the only way out, that they are not even surprised...Friends? Hmm... they weren't there if not for a beer and nor was Krzysiek... I shouldn't be on a wheelchair, I did have a chance for correction but there was no time... it was hard to stay fit while drinking. I don't even have teeth anymore. I hate the wheelchair! I don't even know how to use it... Now the social service, my mother, who is taking the air away from me, and the chair are ruling my life. I could still be independent... For over 20 years you can learn how to be disabled. Disabled and happy, not a drunk cripple..."

One out of ten people in the world is disabled - 650 million people, who as a consequence of mental, physical and sensory disabilities fail or even are not able to lead an active life which is available for healthy people (www.unic. un.org.pl). The disabled, regardless of their visibility, are the citizens of every 
society. According to the Labor Force Survey (Badanie Aktywności Ekonomicznej Ludności) conducted by the Central Statistical Office, 3.4 million people in Poland have the status of a disabled person, which means that $10.7 \%$ of the population aged 15 and more have obtained a legal disability certificate. In 2010 the disabled constituted $8.6 \%$ (about 2.1 million) of people at working age. The main reason for disability are cardiovascular, musculoskeletal and neurological diseases (www.niepelnosprawni.gov.pl).

According to the World Health Organization (WHO), disability is a limitation or lack of abilities to perform activities in a way or in a range considered to be normal for a person. It results from a defect or impairment of the body functions. A disabled person is someone who cannot independently (partly or completely) lead a normal private and socio-occupational life as a result of congenital or acquired impairment of physical and/or mental functions (Gronowska, WilmowskaPietruszyńska, 2007).

In 1994 the European Disability Forum of the European Parliament defined the disabled person as an individual with full rights who is in the situation of being handicapped as a result of environmental, economic and social barriers which, because of the existing damages, cannot be overcome in such a way as other people can (Gronowska, Wilmowska-Pietruszyńska, 2009).

The attempts to find and attribute particular personality traits and skills to the disabled can be relatively easy to find in the literature. Several of the research findings that characterize the disabled are presented below. The findings, however ambiguous, should be taken into consideration while creating programs for the disabled.

MMPI (personality test) based research carried out on different groups of the disabled indicates the increase in the neurotic triad (scales of depression, hysteria, hypochondria) (Kowalik, 2007). The raised depression level can be the result of a justified feeling of sadness. Hysteria symptoms can be a way of expressing disagreement or anger against limitations and higher degree of hypochondria symptoms can reflect the truly experienced pain or other ailments. These findings suggest the existence of neurotic symptoms in the examined group.

Polish research studies from the 1980s, carried out on the group of forty people who had had their lower or upper limb amputated, indicate the distinctions between groups with a different length of disability period. A long period is the time of 10-20 years after the amputation while a short period lasts up to 4 years after the amputation. The results demonstrated that the disabled people with a long period of disability were less skillful and persistent in leadership, showed less desire to take the initiative in social situations and presented higher inhibition, withdrawal into oneself and indifference. They also possessed significantly less adaptation capacity, self-confidence, imagination and did not strive to establish interpersonal interaction. They were more disordered and confrontational, they surrendered to authorities more frequently and they were subordinated to them. They 
were also excessively cautious, suspicious and critical towards the surroundings. It was more common for them to feel the sense of guilt and shame and they were characterized by the lack of self-discipline, self-control abilities and a tendency to exaggerate worries and troubles. Individuals with a short period of disability displayed a higher level of immaturity, passivity, awkwardness, lack of ambition, tendency to show an attitude of resignation and more frequently they were surrendered to individual prejudices. Moreover, they not only were narrow-minded, behaved awkwardly in a social situation and distanced themselves from people but they also tended to be more aggressive, truculent and demanding, complaining about mental discomfort (Jakubik, Szwarc, 1989).

In the literature on psychiatry there appears a term of "homilopathy", which defines a specific type of personality disorders understood as anomalous personality development as a result of handicap or a chronic somatic dysfunction due to obstructive factors preventing from normal relations with the environment or disturbing relations between the individual and social surroundings (Jakubik, 1997). The individuals with homilopathic syndrome are characterized by insecurity, lowered self-esteem, diffidence, poor level of self-acceptance, oversensitivity, sense of threat, caution, self-image disturbance, sense of external control, mood swings, ego weakness and excessive concentration on "myself". They are distrustful in personal contacts and exhibit a tendency to attribute bad intentions to the surroundings (sometimes even delusional attitude). They take the attitude of martyrdom (martyr acceptance of fate) and they manifest malicious, aggressive and even antisocial acts. One of the researchers working on the problem of disability on the basis of the gathered literature highlighted several features attributed to the disabled as the consequences of being disabled. Those features are neuroticism, mental immaturity, suspiciousness, social unpopularity, dissatisfaction with life and withdrawal from activities (Wright, 2004).

The examples of the systematization of the characteristics of the disabled mentioned above on the one hand show some similarities but on the other hand reveal their diversity and difficulty with clear and easy finding of a common denominator. This kind of research is immensely useful, especially while creating assistance programs for the disabled; however, it is worth remarking that the tendency to make a rigid and simplified connection between personality traits and disability can only deepen the stigmatization of an already branded group of people.

It seems that the disabled have become settled in the everyday scenery. Yet this applies mainly to the mass media. Because in fact only a low percentage of the disabled actually function along with the healthy people. The research carried out in 2002 by CBOS (Public Opinion Research Center) showed that as many as $2 / 3$ of the questioned Poles had no contact with the disabled. There are quite a lot of individuals with visible disability, however, in various places, frequently attended my many people, the disabled are still hard to encounter. It is also true of healthcare and help centers. 
Disability is not, however, the only element or determinant of the functioning of the disabled. Just like healthy people, those with disabilities have interests, problems, resources, needs and deficits not directly connected with their disability.

One of the issues concerning both healthy and disabled people is the problem of addiction. Unfortunately, it is difficult to find the number of the addicted among the disabled as well as the number of those undergoing treatment in the alcohol rehab institutions. Manager of the Department of Withdrawal Treatment and Medical Programs at the State Agency for Prevention of Alcohol-Related Problems (PARPA) Jadwiga Fudała speaks about alcohol addiction among the disabled: "Our knowledge about addictions among people with disabilities is minimal. However, if $13 \%$ of adult Poles are those who abuse alcohol yet without features of alcohol dependence and $3 \%$ are addicted, then we have $16 \%$ of the citizens with a problem of this kind. In the socially stigmatized environments, that is also among the disabled, this problem is greater as alcohol is treated as a kind of medicine for problems, stress and isolation"(Przybyszewski, www.niepelnosprawni.gov.pl).

Alcohol dependence is a disease potentially endangering every human being. Individuals who are admitted to dependence treatment centers because of alcohol-related problems, are frequently diagnosed not only with dependence on a given substance but also harmful and risky way of using it. Addiction is defined as a group of physiological, behavioral and cognitive phenomena among which alcohol drinking is predominant. Other behaviors, previously more valued by a given person, are forced out by alcohol. Despite a person's teetotalism, an incident involving drinking alcohol can trigger a relapse of alcohol dependence. To recognize addiction, three or more symptoms from among the following should be identified:

- strong craving or compulsion to drink,

- defective ability to control drinking behaviors,

- occurrence of an alcohol withdrawal syndrome,

- altered alcohol tolerance,

- negligence of the alternative sources of pleasure to the benefit of drinking,

- consuming alcohol despite the occurrence of the evident proof of the harmful consequences of drinking. ${ }^{1}$

Alcohol addiction is a consequence of abusing this substance and it can lead to the negative and subsequently destructive effects for both a drinker and his or her surroundings. Alcoholism is a disease destroying the individual with respect to all of his or her personality aspects and it ends with the complete degradation of psychological, spiritual and social life. The loss of the ability to function properly in a family and the society is a result of drinking.

\footnotetext{
1 Klasyfikacja zaburzeń psychicznych i zaburzeń zachowania w ICD-10: Opisy kliniczne i wskazówki diagnostyczne. Uniwersyteckie Wydawnictwo Medyczne "Vesalius" i Instytut Psychiatrii i Neurologii. Kraków - Warszawa, 2000.
} 
Alcohol dependence is a strong mechanism stimulating its consumption and modifying its impact on both short-lived diseases, chronic diseases and with the detriment to the society. Alcoholism is a result of the long-lasting alcohol abuse. The disease concept of alcoholism was first published by E. Jellinek. He distinguished four phases in the process of the disease's development:

- Phase 1 - pre-alcoholic or symptomatic phase - initially only socially motivated use of alcohol; alcohol is used to reduce the feeling of sadness and other unpleasant emotional states; this phase is characterized by the increase in alcohol tolerance and can last from several months to a couple of years;

- Phase 2 - premonitory phase - an individual starts having first blackouts and does not remember the circumstances of drinking; he or she searches for an occasion to have a drink simultaneously feeling the remorse; the main symptoms in this stage are consuming alcohol in order to boost the spirit; the individual starts looking for the occasion to drink and starts drinking alone or in prohibited places, like at work;

- Phase 3 - crucial phase - in this stage an individual is not able to control his or her drinking habits, starts making excuses for his or her drinking, becomes aggressive towards surroundings, at the same time feeling remorse because of his or her behavior. The addicted person wants to prove that he or she controls alcohol consumption, therefore attempts of abstinence can occur in this stage; there appear health-related problems as well as the compulsion to drink;

- Phase 4 - long-lasting benders and gradual decrease in alcohol tolerance are typical; sleep and mental ability disorders occur; if medical treatment is not present in this phase, the disease can lead to death.

Motives for drinking are different; people drink to feel relaxed, to feel better, to have fun or to gain the adequate position in a peer group.

Literature touching upon this subject mentions the following reasons for drinking:

- Drinking "to escape" - to forget about problems, to boost the spirit, to reduce tension and to relax;

- Social reasons - drinking for company, out of pleasure or on the occasion of something;

- Drinking to find pleasure - for the taste of alcohol or because of the belief in alcohol's healing properties.

As a result of alcohol abuse, the alcohol withdrawal syndrome arising from an attempt to avoid alcohol or consuming smaller doses can occur. The addicted individual has an impression that the body craves for alcohol and the main symptoms are: tiredness, anxiety, stomach disorders, hyperexcitability, hyperhidrosis, hypertension, hands trembling, headaches, insomnia.

Excessive consumption of alcohol has a negative impact on a person's health. Loss of control over drinking is typical for the addicted. Alcohol has depressive effects on the central nervous system initially by limiting the brain's control 
center, therefore it is typical for the first phase to feel relaxed and free. Gradually the limitation covers more extensive parts of cortex, which in consequence leads to coma and death. States of anxiety and sleep disorders are additional negative impacts of psychological nature. Excessive doses of alcohol cause brain damage and in consequence bring the reduction of cognitive abilities leading to dullness. Abusing of alcohol may not only be the reason for numerous family-related problems but can also cause family breakdown. The marital relationship becomes unsettled when aggressive and violent actions are involved.

As far as cultural specificity is concerned, Jellinek distinguished five types of alcoholism:

1. Alpha alcoholism - so-called life in exhilaration; an individual is able to control the amount of consumed alcohol and states of intoxication are rather rare; drinking has psychological and escaping-type background and effects are seen mainly in the disturbance of social relations;

2. Beta alcoholism - a person consumes alcohol irregularly but in great amounts and very often (along with malnutrition, it can lead to health-related problems, such as gastritis, esophagus inflammation, cirrhosis of the liver, inflammation of the kidney, bladder, pancreas damage and problems with the nervous system, etc.)

3. Gamma alcoholism - a body's tolerance to alcohol becomes higher, which leads to an increase in alcohol consumption; there is full-blown physical and psychological dependence;

4. Delta alcoholism - an individual drinks regularly but can control the amount consumed; the person finds it hard to abstain from alcohol for a longer period of time; there is a constant increase of alcohol in the body;

5. Epsilon alcoholism - or periodic alcoholism; this type is marked by binge drinking, that is when longer or shorter periods of abstinence are disrupted by relapses lasting for several days; social events, meetings and family celebrations become excuses for drinking.

According to Jellinek, only Gamma, Delta and Epsilon types can be called alcoholics.

The diagnosis of alcoholism means that a person in not able to have a reliable picture of the situation in every moment of the drinking period and is not aware of the amount consumed. Moreover, pathological organic changes can be detected in almost every organ but usually in liver, brain, peripheral nervous system, and in alimentary and excretory canals. It is also assumed that the social, emotional symptoms and behavioral consequences of alcoholism are the results coming from the impact of alcohol on the functioning of the brain. It depends on cultural or group standards what level and intensity of symptoms will be classified as deviant.

Not every person reporting the problem with alcohol has to be diagnosed as an addict. According to the International Statistical Classification of Diseases and 
Related Health Problems (ICD-10), harmful use of alcohol is also distinguished, which is understood as the model of drinking that causes health-related somatic and psychological damages. These damages, however, have to be simply diagnosed as the result of alcohol drinking. Diagnosis of addiction excludes the diagnosis of harmful use ${ }^{1}$.

Risky drinking is not a disease entity. It means that alcohol is abused without any negative results, however, if the current drinking model is not changed, harmful consequences can be expected in the future (Fudała, 2009). The main reason why an individual reaches for psychoactive substances is a change in the actual emotional state: I drink/use: "for pleasure", "to relax", "for fun", "to forget" (Krawczyk, Satora, Brzyski, 2008). The majority of people aim to balance their emotional state in favor of experiencing positive feelings. Natural methods for boosting the spirits, on the one hand, require taking an action which is seen as beneficial and valuable but, on the other hand, avoiding threatening and disadvantageous situations. These actions usually require activity, openness towards other, interpersonal abilities but they are also dependent on numerous, broadly defined individualistic resources (optimism-pessimism, level of anxiety, meaning of life, self-support, etc.).

Alcohol is a substance strongly affecting the central nervous system. Under a significant influence are those functions which are connected with the biochemical regulation of phenomena and psychological activities, including emotional ones. After drinking alcohol, unpleasant feelings and thoughts are usually gone; sadness fades away, subjectively felt level of tension declines and carefreeness occurs (Mellibruda, 2006). Despite taking this "shortcut", the majority of people do not get into troubles with drinking. There is, however, a group of people for whom alcohol becomes more and more important and finally is the only way to affect one's own emotional states. One of the theories explaining addiction holds that it is the effect of the interaction of two factors: physical pain and inability to cope with it (Simons et al., 1991; Clark, Sayette, 1993). Repetitive and intensive experiencing of unpleasant moments can create in human the fixed source of sadness, fear or anger, which in consequence can be the reason for their occurring regardless of the current situation (Mellibruda). It is just one aspect of the multifactorial grounds of addiction but in case of the disabled it seems to be the factor which can be a significant method of predisposing them to the risk group.

\section{The Specific Character of Working with the Disabled}

As it was previously mentioned, the alcohol problem can afflict anybody, regardless of the status, health condition, gender or skin color. According to a popular opinion, addiction is a consequence of biological, psychological and social factors. This is not the subject of this thesis, however, it is worth pointing out 
several of the psychological factors which predispose one to overuse or to become addicted to alcohol. It is not difficult to notice that many of them agree with the description of the disabled. Low self-esteem, loneliness, concentration on oneself, lack of sense and aim, feeling of disgrace, difficulties with handling unpleasant emotions, poor abilities of coping with stress, poor sense of control and difficulties with interpersonal contacts, etc. are conducive to using alcohol as the substance which can change the mood in a fast and easy way (Mellibruda, 2006). The psychological theories explaining the reasons for addiction repeatedly treat alcohol as the way of reducing tension, fear and other unpleasant feelings (Cierpiałkowska, 2000). Alcohol is the strategy of helping to cope with various, broadly defined human problems. To some extent the disabled have predispositions to get into addictions but that does not mean they will become addicted. Dependence is a multifactorial disease resulting from the coincidence of numerous phenomena, features and experiences. However, if the disabled person appears in the withdrawal treatment center, it is good to remember the he/she is heavily burdened with deficits of functioning in everyday life, which is a consequence of both barriers to disability and the closed circle of addiction.

The experience of the authors of this publication shows that in the therapy of the disabled who were qualified for withdrawal treatment a few crucial and persistent problems should be taken into consideration. It is obvious that the disabled, like other people, participate in both basic- and advanced-level therapeutic programs for those with addiction problems. The aspects to which attention has been paid below have been chosen not because they are characteristic for this group of patients as they relate to the majority of the addicted, but in the case of disability they become more powerful. Working on these aspects seems to be an indispensable element of the therapy for the disabled asking for psychological help.

\section{The Meaning and Quality of Life}

The meaning of life is, in general, the sense that certain aims are realized and the life has value. It is also a conviction that an individual can influence his or her own life and feels the sense of his or her importance (Baumeister, 1986; Popieralski, 1987). The need for the meaning of life is, along with the need of emotional contact and cognitive need, considered to be one of the orienting needs (Obuchowski, 1973). The object of the orienting needs are external situations and one's own actions connected with the orientation in surroundings (responding to phenomena or objects in accordance with their importance for a given person). Meeting the orienting needs constitutes an indirect condition for keeping the person's inner balance ${ }^{76}$. Among the trends in psychotherapy there is logotherapy developed by Frankl. According to logotherapy, sensible behavior based 
on certain values as the way to achieve the explicit aim is the condition of health and inner satisfaction. Human life is connected with experiencing the meaning of life. A lack of the meaning of life (the existential void) can lead to different kinds of emotional disorders. According to Frankl, the interpretation of life events as senseless as well as difficulties with defining their meaning release fear, anxiety and both psychological and physical suffering (Grzesiuk, 1998). The sense of life was an object of interest for many prominent Polish and foreign scholars. For the needs of our program we adopted the definition of the meaning of life suggested by Baumeister (1986). This American psychologist enumerates four elements indispensable for the proper understanding of the meaning of life. He established that life is meaningful if:

- Certain far-reaching aims are being realized,

- Life is formed by the values derived from the certain philosophy of life or from education,

- The individual has control over the course of life,

- The individual feels his or her value and importance ${ }^{63}$.

Those who feel the senselessness of life are characterized by the fear of the future, apathy, sense of being lost and solitary in the world. The result of that is withdrawal and avoiding taking responsibility for one's own life. The lack of community feeling, cynical attitude, giving up the possibility to develop talents and the negation of values appear (Szymanowska, 1990). The functioning of this kind, without the possibility to solve the dilemma with regard to the aim or sense of life in a constructive way can, unquestionably, lead to the use of alcohol as a substance allowing to forget, to fill in time but is also an excuse for not taking actions. In E. Konieczna's research it was determined that the experienced level of the meaning of life is influenced by, among others, the sense of one's effectiveness, optimism as well as the acceptance of one's disability (Konieczna, 2010).

While leading the disabled person through the therapy, it is worth looking more closely at these factors and make an attempt to modify them. The disabled repeatedly notice only their disabilities, forgetting about the healthy side of their person. Working on this aspect is immensely difficult and long-lasting, however surely profitable. Attention should be paid to the seeming adaptation or acceptance of disability. During the treatment, numerous difficulties connected with not noticing the sense or value of different activities (attitude of resignation) can be revealed. The disabled are usually the justified unemployed (most often pensioners). One should also remember that occupational activity influences the meaning of life. It is necessary to find the value and motivation to take up this activity.

Taking disability into account, one should take up actions to reinforce and broaden the values. It turns out that working on the hierarchy of values and forming goals (far- and short- reaching) and searching for ways to develop is immensely important. The disabled repeatedly do not see the possibilities to develop. They are concentrated on the impossibility to realize their dreams and goals because of 
their disabilities which are often exaggerated and seen inadequately. Using the small steps method, one should try to reinforce the trust in one's effectiveness, importance and significance of one's desires - that means to help discover the life anew and reinforce the motivation for staying sober.

\section{Social Competence}

In the literature there is usually a distinction between the terms of social competence and skills, however, for the needs of this thesis it does not seem to be necessary to expand those theories and for simplicity the terms will be used alternately. Social competencies are to a great extent conditioned by personality traits, temperament or intelligence (constant features). However, if they are understood as the complex abilities used to deal with social situations then, despite the conditioning, we have an influence on their reinforcement. Thanks to the improvement of the social competence, it is possible, among others, to reach goals in the social life and to build satisfying emotional bonds.

Mellibruda (2003) distinguishes four aspects of interpersonal relations referring to psychosocial skills:

- Building the atmosphere of mutual trust,

- Dealing with problems and conflicts,

- Mutual understanding and getting to know each other,

- Helping and exerting an influence,

Rinn and Markle mention the categories of behaviors essential for social skills:

- Reinforcement skills,

- Communication skills,

- Self-assertion skills,

- Self-expression skills (Oleś, 1998).

The reinforcement of social skills belongs to the basic goals of the therapy at all. The social contacts of the disabled are usually limited and in contacts they feel insecure and socially unattractive. The withdrawal also hinders the abilities of showing their skills on the labor market which, as mentioned above, is an essential element of reinforcing the meaning and aim of life.

The previously mentioned feeling of shame, reduced value and lack of selfassertion are conducive to isolation and hinder the creation of the constructive ways of dealing with interpersonal contacts. Repeatedly, as it can be imagined, alcohol can constitute the only way for freedom or cessation of contacts at all.

Focusing on the three groups of skills:

- Self-assertion - the recognition that one is as important as others; representing one's own interests (needs, rights, emotions) without crossing the line or violating other people's rights. 
- Communication - the process of exchanging information (needs, rights, emotions) in the coherent verbal and nonverbal form which is clear for others.

- Social exposure - presenting oneself in a favorable light, adjusting one's way of behavior, attitudes and appearance to the recipients' expectations and preferences (Borkowski, 2003). It is an element of self-presentation. It is a method of "acting in a certain way only to make a good impression which, undoubtedly, elicits the desirable reaction" (Szmajke, 1999).

In the psychotherapeutic work, the naming of one's needs, emotions and attitudes is a very important element. It usually turns out that until the reinforcement process of social competence is proceeded when the opportunity occurs ("by the way"), particular difficulties are not exposed. They only become visible in conscious caring about the effectiveness of using social competence in interpersonal contacts. In this situation, it is useful to refer to the experience when the skills were used unconsciously, which gives an opportunity to use the resources and to believe in efficacy. Attention should be paid to the subjective perception of the reality, incorrect form of statements, false expectations towards the interlocutor, parallel communication (a fight to win) and discrepancy in communication (verbal and nonverbal). As it was previously shown by citing the research, reactions of oversensitivity, avoidance or malevolence in interpersonal contacts can be observed among the disabled. They often expect a negative evaluation from others or disrespectful, pitiful or hostile attitudes towards them. This approach implies a response, so the functioning in relationships can be seriously hindered. The aspects of the perception of interpersonal reality by patients are worth taking into consideration while working on social competence.

It is worth paying attention to actions aiming at the reinforcement of interpersonal skills essential in the situation of being in the center of attention and potential evaluation (e.g. while looking for a job) or in situations when one has to resist others' influence or wants to realize one's own goals and needs. Particular attention should also be paid to the reinforcement of faith in the efficacy of one's statements as well as to providing successive "tools" aimed at improving communication. Even though it meets resistance from the disabled, they should be directed to workshops of every kind to improve their communication skills. According to the literature on this subject, the level of social competence depends partly on the level of emotional intelligence. Emotional intelligence which is understood as the ability to use emotions for coping with problems (Jaworowska, Matczak, 2001). In order to choose psychological influence which can reinforce emotional intelligence, one can use the concept by Mayer et al. (2000). This model assumes the existence of four branches of emotional intelligence: ability to perceive and understand emotions, assimilate emotions in the cognitive process, understand and analyze emotions as well as the ability to control and regulate them (Mayer, Salovey, Caruso, 2000). Reinforcing these skills gives a chance to process the emotional information effectively and at the same time to use emotions not only 
to raise social competence but also to handle problems. Thanks to the mentioned endeavors, it is possible to eliminate the need of using alcohol as a way for interpersonal contacts and as a way to cope with frustration in relations.

\section{Body Image}

It has to be honestly admitted that this element of therapeutic work is often ignored or treated in a superficial way. A body image is a part of a self-image. The attempts to separate (e.g. as a result of the rejection of self-acceptance) one's body from the rest of "self" result in difficulties on the interpersonal levels of intimacy, social expression, love relationships, self-presentation. It has to be remembered that the body is the source of expression and emotions; through the body one expresses the frame of mind and the attitude towards the world. Separation from the body's sensations is a separation from one's needs (sexual, emotional, weariness as well as the needs of rest, hunger, etc.) The communication on the intimate and social level happens through the body (Lelek, Krawczyk, Bętkowska-Korpała, 2012). Negligence of the importance of the body's sensations can lead to fear, depression and interpersonal difficulties (Lelek, Krawczyk, Bętkowska-Korpała, 2008). The bodiliness is associated with the attractiveness and sense of one's value and the shortage of those is equal to the lack of self-acceptance. This element of work seems to be important in this group of patients and it is worth devoting more time to this problem. Alcohol can serve to improve self-assessment and by reducing the feeling of shame and inhibitions it can be the only way to function in intimate relations. Unfortunately, alcohol can also be conductive to risky sexual behaviors.

On the other hand, unreasonable concentration on the body can lead to excessive identification with the disabled (therefore unaccepted) parts of the body. The individual forgets that apart from the disabled parts of the body he also has parts which are healthy and attractive. Concentration only on the negative body signals can reduce the level of self-assessment and can indirectly lead to avoiding interpersonal contacts and focusing attention on unpleasant and painful sensations.

The subject of body image is a difficult topic, especially among the people with the motor disability. However, as proved by the author's experience and literature reports confirming the importance of the subject, it is worth devoting some more time and attention to it by working on getting accustomed to one's body and making it more real as well as at the same time allaying the fears and overcoming complexes concerning one's bodiliness. Introduction of the activities taken from dance therapy and methods of relaxation can also be helpful. Activities using movement psychotherapy are worth introducing (obviously if adjusted to the patients' possibilities). Because the work on the body's image requires a high level 
of intimacy, this issue should be introduced carefully and at the advanced level of withdrawal treatment. Working through the issue of the body image aims at getting or reinforcing self-acceptance and self-awareness and, in consequence, it has a great impact on self-assessment, interpersonal functioning and coping with emotions.

The mentioned aspects are, in principle, basic while working with the disabled having an alcohol-related problem and the whole process means intensive work of the disabled on oneself with special assistance and care.

It seems to be essential to adjust therapeutic programs to the specific character of the disorders afflicting the disabled.

\section{References}

Baumeister, R. F. (1991). Meanings of Life. New York: Guilford Press.

Borkowski, J. (2003). Podstawy psychologii społecznej. Warszawa: Dom Wydawniczy ELIPSA

Cierpiałkowska L. (2000). Alkoholizm. Przyczyny - Leczenie - Profilaktyka. Poznań: Wydawnictwo naukowe.

Clark D.B., Sayette M. A. (1993). Anxiety and the development of alcoholism. The American Journal on Addictions, 2(1), p. $59-76$

Grzesiuk L. [Ed]. (1998). Psychoterapia. Warszawa: Wydawnictwo Naukowe PWN.

Fudała J. (2009). Rozpoznanie osób pijacych alkohol w sposób ryzykowny i szkodliwy [In:] B.

Bętkowska Korpała B.[Ed] (2007). Uzależnienia w praktyce klinicznej. Warszawa: Parpamedia.

Gronowska Z, Wilmowska-Pietruszyńska A.: Niepełnosprawność, a całkowita niezdolność do pracy. Arch. Med. Sad. Krym., LVII, 6-10

Jakubik A. (1997). Zaburzenia osobowości. WL PZWL, Warszawa, p. 102 - 106.

Jakubik A., Szwarc K. (1989). Homilopatia. Problemy Rehabilitacji Zawodowej, 3, 17-23.

Konieczna E. (2010). Poczucie sensu życia osób niepetnosprawnych ruchowo. Kraków: Impuls.

Kowalik S. (2007). Psychologia Rehabilitacji. Warszawa: Wydawnictwo Akademickie i Profesjonalne.

Krawczyk-Pasławska E. (2010). Niepetnosprawność. Bariery i szanse. Kraków: Nasza oficyna Krzysztof Kopacz.

Krawczyk E., Satora L., Brzyski P. (2008). Przyjmowanie substancji psychoaktywnych przez studentów polskich uczelni - wstępny raport z badania w ramach Sieci Uczelnie Wolne od Uzależnień [In:] Pach J., Konieczny J. [Ed.]. Medyczne czynności ratunkowe w zatruciach i skażeniach chemicznych. Inowrocław - Poznań - Kraków: Garmond Oficyna Wydawnicza.

Lelek A., Bętkowska-Korpała B. (2008). Doświadczenie własnego ciała u kobiet z syndromem dorosłego dziecka alkoholika (DDA)- doniesienie z badań. Psychoterapia, 4(147), 43-51.

Lelek A., Krawczyk E, Bętkowska- Korpała B. (2010). Zaburzenia obrazu własnego ciała a funkcjonowanie $w$ relacjach spolecznych $u$ kobiet z syndromem Dorosłego Dziecka Alkoholika (DDA) - implikacje terapeutyczne. [In:] Gąsior K., Chodkiewicz J. [Ed]: Leczenie alkoholików i członków ich rodzin. Perspektywa badawcza i praktyczna. Kielce: Jedność.

Mayer J.D, Salovey P., Caruso D. (2000). Models of emotional intelligence. [In:] Sternberg R. Handbook of intelligence. Cambrige.

Mellibruda, J. (2003). Ja, ty, my. Psychologiczne możliwości ulepszania kontaktów międzyludzkich. Warszawa: IPZ. 
Mellibruda J. (1994). Nałogowa osobowość naszych czasów. Lectures in Remedium and: http:// www.psychologia.edu.pl/czytelnia/50-artykuly/719-nalogowa-osobowosc-naszych-czasow. html [20.10.2012]

Mellibruda J. Sobolewska - Mellibruda Z. (2006). Integracyjna psychoterapia Uzależnień. Warszawa: IPZ.

Obuchowski K. (1973). Psychologia dążén ludzkich. Warszawa: PWN.

Oleś M. (1998). Asertywność u dzieci. Lublin: Towarzystwo Naukowe KUL.

Popielski K. (1987). Testy egzystencjalne:metody badania frustracji egzystencjalnej i nerwicy noogennej. [In:] Popielski K. [Ed]. Człowiek-pytanie otwarte. Studia z logo teorii i logo terapii. Lublin: Wydawnictwo KUL.

Simons R.L., Whitbeck L.B., Conger R.D., Melby J.N. (1991). The effect of social skils, values, peers, and depression on adolescent substance use. Journal of Early Adolescence, 11(4), p. 466-481.

Shontz F.C. (1977). Physical disability and personality: Theory and recent research [In:] Stubbins J. [Ed.]: Social and psychological aspect of disability. Baltimore: University Park Press, p. 333-353.

Szmajke, A. (1999). Autoprezentacje. Olsztyn: Ursa-Consulting.

Szymanowska A. (1990). Problematyka poczucia sensu życia. [In:] Ostrowska K [Ed]. Atak-rezygnacja: strategie działania. Warszawa: Centralny Program Badań Podstawowych

Wilmowska-Pietruszyńska A. Zabezpieczenie społeczne ryzyka choroby i jej następstw - niezdolności do pracy i niezdolności do samodzielnej egzystencji w Polsce. Stan aktualny i proponowane zmiany. Postepy Nauk Medycznych, 4/2009, p. 256-263

Kowalik S., (2007). Psychologia Rehabilitacji. Warszawa: Wydawnictwo Akademickie i Profesjonalne, 54-55

http://www.unic.un.org.pl/niepelnosprawnosc/?cos=1. [24.11.2011]

http://www.niepelnosprawni.gov.pl/niepelnosprawnosc-w-liczbach/

T. Przybyszewski. Na dno bez barier. http://www.niepelnosprawni.pl/ledge/x/11716?print_doc_ id $=81177$ 2011-01-26 [20.10.2012]

Klasyfikacja zaburzeń psychicznych i zaburzeń zachowania w ICD-10: Opisy kliniczne i wskazówki diagnostyczne .Uniwersyteckie Wydawnictwo Medyczne "Vesalius" i Instytut Psychiatrii i Neurologii. Kraków - Warszawa, 2000. 